\title{
Assessment of Hematological Parameters and Uterine Hemodynamic Indices in Bitches with Pyometra
}

\author{
Zeynep Günay Uçmak', İbrahim Kurban² \& Melih Uçmak
}

\begin{abstract}
Background: Pyometra is defined as chronic purulent inflammation of the uterus that causes changes in hematological and biochemical parameters. The disease is characterized with bacterial infection and pus accumulation in the uterus. Transabdominal B-mode ultrasonography provides easy and certain diagnosis of this disease. The hemodynamic changes in pyometra are evaluated by Doppler ultrasonography. The aim of the study is to determine the changes in hematological parameters and Doppler indices in bitches with pyometra, diestrus healthy bitches and evaluate the relationship between hematological parameters and hemodynamic indices within the both groups.

Materials, Methods \& Results: A total number of 27 bitches were enrolled in the study. The healthy diestrus bitches (group $\mathrm{H} ; \mathrm{n}=7$ ) aged $6.2 \pm 1.14$ years, weighted $14.57 \pm 3.75 \mathrm{~kg}$. The bitches with pyometra (group PYO; $\mathrm{n}=20$ ) aged $9.1 \pm 0.62$ years and weighted $17.65 \pm 2.60 \mathrm{~kg}$. Before all bitches had ovariohisterectomy, hematological analyses were performed. Transabdominal ultrasonography (USG) was performed with a $6.6 \mathrm{MHz}$ convex transducer. The widest cross-sectional uterine diameter (UD), wall thickness of uterine horns (UWT) and presence of luminal content were evaluated. Diameter of the uterine artery (DUA) was measured on a mapped color image using the USG software program. The examination was carried out with pulsed-wave Doppler USG to characterize the waveform of the uterine artery (UA). Anechogenic areas in uterine lumen, increase in UD and UWT were observed in group PYO. All cases in group PYO had luminal content in both uterine horns ranging from 1.2 to $5.6 \mathrm{~cm}$. The DUAs were measured in group $\mathrm{H}$ and in group $\mathrm{PYO}$ as $1.75 \pm 0.03$ $\mathrm{mm}, 1.94 \pm 0.08 \mathrm{~mm}$; respectively $(P<0.05)$. The PI and RI values of group PYO were lower than group $\mathrm{H}(P<0.001)$. Hematological analysis results showed that RBC, HGB, HCT levels in group PYO were lower than group $\mathrm{H}(P<0.001)$. However, WBC, NEU, LYM, MONO levels in group PYO were higher than group H. Hemodynamic indices were positively correlated with RBC, HGB, HCT, whereas they were inversely correlated with NEU, WBC, UD and UWT. Also, PI value was negatively correlated with MONO.

Discussion: Cystic endometrial hyperplasia (CEH) is a predisposing factor for development of the pyometra in bitches. Besides, naturally occurring $\mathrm{CEH}$ and pyometra can arise independently from each other. The enlarged uterine body exhibits the development of intense exudative processes due to the higher proliferative stimulation in uterine infections. Uterine infections were associated with increase in uterine blood flow. Elevated uterine blood flow, vasodilatation and angiogenesis arise during inflammatory response. The inflammatory process leads to a diminution in hemodynamic indices of uterine arteries. Total blood count parameters are affected from the presence of pyometra. Elevated levels of leukocytes in bitches with pyometra are associated with worsening prognosis. Erythrocyte diapedesis into the lumen of the uterus, toxic depression of erythropoiesis in the bone marrow can cause anemia. In conclusion, hematological parameters were strongly correlated with hemodynamic indices in this study. Reduced RBC, HGB and HCT levels, decreased PI and RI values and elevated levels of UD, UWT, DUA were observed in group PYO. To our knowledge, this was the first study that observed the increase in DUA during pyometra in bitches.
\end{abstract}

Keywords: bitches, doppler, hemogram, pyometra, ultrasound, uterine artery. 


\section{INTRODUCTION}

Pyometra is a chronic purulent inflammation of the uterus and it is one of the most common diseases of intact bitches. The disease is characterized with bacterial infection and pus accumulation in the uterus [15]. Pyometra can occur from 4 months to 16 years of age [17]. Repeated administration of exogenous progesterone for contraception leads to pyometra formation [24]. Hemorrhagic and mucopurulent vaginal discharge is noticeable in pyometra with an open cervical canal. Besides, more severe clinical signs and abdominal enlargement frequently occur in pyometra with closed cervical canal $[13,21]$. The disease causes changes in hematological parameters [19].

Diameters of uterine horns, thickness of the uterine wall and presence of luminal content can be evaluated by B-mode ultrasonography (USG) [27]. Doppler USG is commonly utilized to evaluate the hemodynamic changes in the female genital tract $[5,6]$. Color Doppler USG is a non-invasive technique that provides the quantitative evaluation of endometrial vascularization in uterine diseases [27]. Qualitative assessment of blood flow in uterine arteries is performed by spectral Doppler USG. Whereas blood flow behavior is measured by velocities; peak systolic velocity (PSV), end diastolic velocity (EDV), mean velocity (MV), impedance of the vessels therefore vascular supply of the organs are assessed by derivation of the indices; resistivity indices (RI) and pulsatility indices (PI) $[10,12]$.

The aim of the study is to determine the changes in hematological parameters and Doppler indices in bitches with pyometra, diestrus healthy bitches and to evaluate the relationship between hematological parameters and hemodynamic indices within the groups.

\section{MATERIALS AND METHODS}

\section{Animals}

A total number of 27 bitches were enrolled in the study. All bitches were clinically (heart rate, respiratory rate, body temperature and dehydration status) and gynaecologically (inspection of vulva, vaginoscopy, vaginal cytology and trans-abdominal USG) examined. The nonpregnant bitches with healthy genital tract at diestrus (group $\mathrm{H} ; \mathrm{n}=7$ ) aged $6.2 \pm 1.14$ years, weighted 14.57 $\pm 3.75 \mathrm{~kg}$ which had pro-estrus bleeding 2-3 months ago. The bitches in group $\mathrm{H}$ were presented to the clinic for ovariohysterectomy. The bitches with pyometra (group PYO; $\mathrm{n}=20$ ) aged $9.1 \pm 0.62$ years and weighted 17.65 $\pm 2.60 \mathrm{~kg}$. Hematological analyses were performed for all bitches in pre-operative term to avoid the anesthesia complications. Ovariohysterectomy was performed to treat the pyometra.

Vaginal cytology

Vaginal smear was obtained for cytological examination of the vagina for both groups. The smears were stained with Diff-Quick stain set ${ }^{1}$ according to the manufacturer's instructions. Slides were examined by a light microscope ${ }^{2}$ at $\mathrm{x} 400$ magnification.

\section{Gynaecological USG}

Internal genital tract (ovaries and uterus) was examined trans-abdominally by the same operator in both groups with B-mode USG equipped with 6.6 MHz convex transducer ${ }^{3}$. The bitches were positioned in dorsoventral position and gently restrained. No sedation was used. The widest cross-sectional uterine diameter (UD), wall thickness of uterine horns (UWT) and presence of luminal content were visualized on left and right uterine horns and calculated automatically by the USG equipment software. The vessels (iliac artery, uterine artery (UA), uterine vein) and the blood flow on the uterus were mapped by color flow mode of Doppler USG using a 5.5-MHz transducer ${ }^{3}$ as Veiga et al. [36] reported. Diameter of the uterine artery (DUA) was measured on a mapped color image using the USG software program. The examination was carried out with pulsed-wave Doppler USG to characterize the waveform of UA. The angle of insonation was approximately $60^{\circ}$ during spectral measurements. At least three consecutive systolic peaks with similar amplitude and velocity were included for analysis. The PI and RI values of UA were automatically calculated by the Doppler machine software ${ }^{3}$.

\section{Blood sampling and hematological analysis}

Blood samples were obtained with the puncture of the vena cephalica antebrachii by using sterile 21 gauge cannula into the ethylendiaminetetra-acetic acide (EDTA) containing vacutainer tube ${ }^{4}$ for each bitch. Hematological analysis was performed by using hematology analyzer ${ }^{5}$. Red blood cell (RBC), hemoglobin (HGB), hematocrit (HCT), white blood cell (WBC), neutrophil (NEU), lymphocyte (LYM), monocyte (MONO) measurements were incorporated into the study.

\section{Statistical analysis}

Statistical analyses were performed with SPSS 13.0 package program ${ }^{6}$. The normal distribution of the 
Z.G. Uçmak, I. Kurban \& M. Uçmak. 2021. Assessment of Hematological Parameters and Uterine Hemodynamic Indices in Bitches with Pyometra.

Acta Scientiae Veterinariae. 49: 1796.

data was checked by using Shapiro-Wilk test. Student's $t$-test was performed for the comparison of the groups with regard to the hematological parameters and USG measurements. The Pearson correlation was used to determine the relationships among the parameters evaluated. Values were given as mean \pm standard error of the mean (SEM). The significance level was accepted as $P<0.05$.

\section{RESULTS}

Body temperature, heart rate, respiratory rate and dehydration stage were within normal ranges in healthy diestrous bitches whereas elevated levels of these parameters were observed in group PYO. Based on the presence or absence of the vaginal discharge in per vaginal examination, the bitches in group PYO were categorized according to cervical patency. Depend on the anamnesis and gynaecological examination of the bitches with closed cervical canal ( $n=6$ ) had lethargy, anorexia, abdominal enlargement, polyuria and polydipsia. In addition to lethargy, anorexia, the bitches with open cervical canal $(n=14)$ had malodorous, purulent and dense consistency vaginal discharge and vomiting. In both groups, there was neither vulva-vaginal neoplasia, vaginal rupture nor vaginal hyperplasia occurred. In vaginal cytological examination, intermedier and parabasal cells with some neutrophills were visualized in smear belong to group $\mathrm{H}$. In addition to intermedier and parabasal cells, group PYO had bacterial clusters, more neutrophils and pus on the smear background. Each bitch in both groups was in the diestrous stage.

In transabdominal USG, anechogenic areas in uterine lumen, increase in UD and UWT were observed in group PYO (Figure 1). All cases in group PYO had luminal content in both uterine horns ranging from 1.2 to $5.6 \mathrm{~cm}$. However, any cyst formation in endometrium was not detected in bitches with less than $2 \mathrm{~cm}$ UD in group PYO. On the color mapped image of UA in group $\mathrm{H}$ and group PYO, DUAs were measured as $1.75 \pm 0.03 \mathrm{~mm}$, $1.94 \pm 0.08 \mathrm{~mm}$; respectively $(P<0.05)$. Besides, UD and UWT in group PYO were significantly higher than group $\mathrm{H}(P<0.001)$. The PI and RI values of UA in group PYO were lower than group $\mathrm{H}(P<0.001)$ [Figure 2]. The UD, UWT, DUA and PI and RI values of UA related to the groups and their significance were presented in Table 1. In group PYO, UD, UWT, DUA, PI and RI of UA were not significantly associated with open or closed cervix pyometra $(P>0.05)$. Hematological analysis results showed that RBC, HGB, HCT levels in group PYO were lower than group $\mathrm{H}(P<0.001)$. However, WBC, NEU, LYM, MONO levels in group PYO were higher than group $\mathrm{H}$.
Mean values and SEM of hematological analysis results related to the groups and their significance were given in Table 2. In group PYO, values of RBC, HGB, HCT, WBC, NEU, LYM, MONO were not associated with open or closed cervix pyometra $(P>0.05)$. The Pearson correlation assessment of hematological parameters and hemodynamic indices were presented in Table 3.

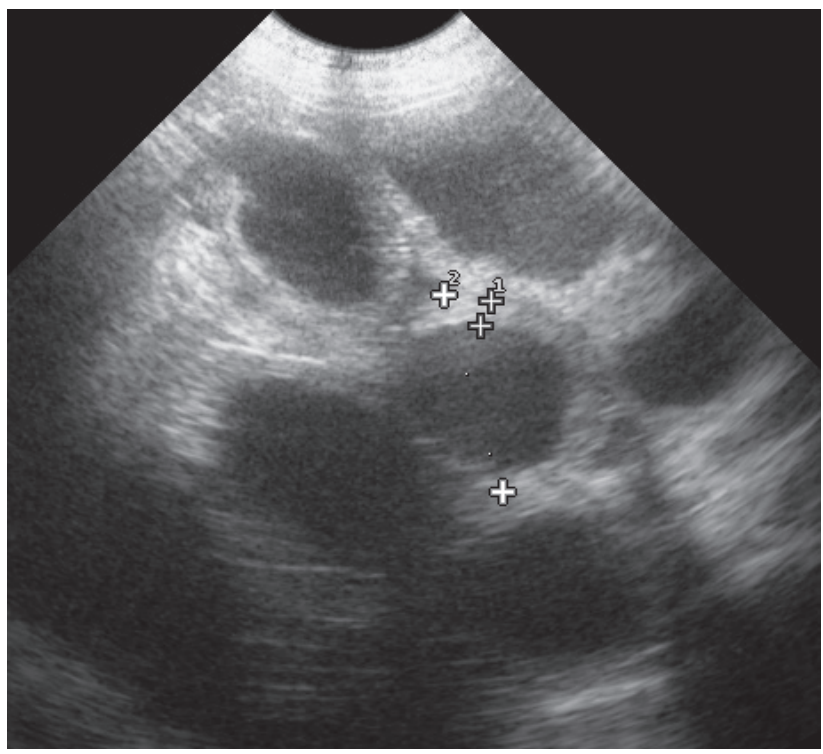

Figure 1. B-mode trans-abdominal USG in a bitch with pyometra. D1: Uterine wall thickness \& D2: Uterine diameter.

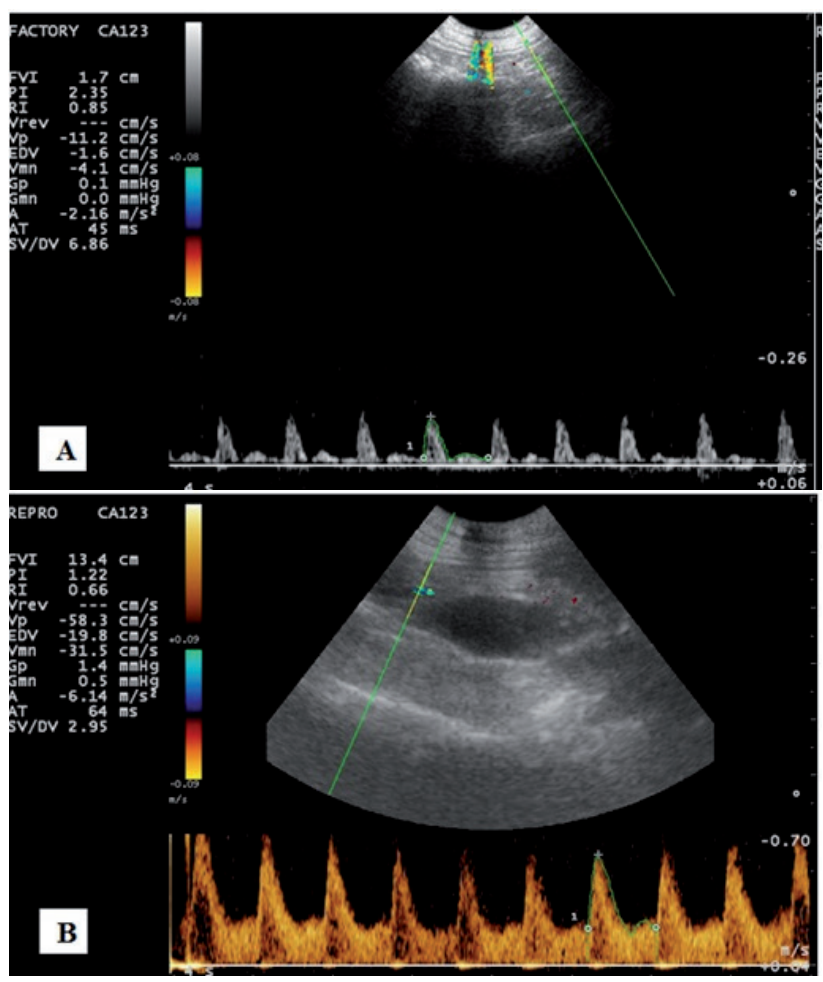

Figure 2. Pulsed wave Doppler USG images belong to uterine artery. AElevated PI and RI values in a diestrus healthy bitch. B- Reduced PI and $R I$ values in a bitch with pyometra. 
Z.G. Uçmak, İ. Kurban \& M. Uçmak. 2021. Assessment of Hematological Parameters and Uterine Hemodynamic Indices in Bitches with Pyometra.

Table 1. Mean \pm SEM of UD, UWT, DUA, hemodynamic indexes and their significances.

\begin{tabular}{|c|c|c|c|c|c|}
\hline Group & $\mathrm{UD}(\mathrm{cm})$ & UWT (cm) & DUA $(\mathrm{mm})$ & PI of UA & RI of UA \\
\hline PYO & $2.62 \pm 0.28$ & $0.31 \pm 0.02$ & $1.94 \pm 0.08$ & $1.20 \pm 0.04$ & $0.65 \pm 0.01$ \\
\hline \multirow[t]{2}{*}{$\mathrm{H}$} & $0.54 \pm 0.02$ & $0.09 \pm 0.00$ & $1.75 \pm 0.03$ & $2.25 \pm 0.05$ & $0.85 \pm 0.01$ \\
\hline & $* *$ & $* *$ & $*$ & $* *$ & $* *$ \\
\hline
\end{tabular}

Table 2. Mean \pm SEM of hematological parameters and their significances.

\begin{tabular}{cccccccc}
\hline Group & RBC $(\mathrm{M} / \mu \mathrm{L})$ & HCT $(\%)$ & HGB $(\mathrm{g} / \mathrm{dL})$ & WBC $(\mathrm{K} / \mu \mathrm{L})$ & $\mathrm{NEU}(\mathrm{K} / \mu \mathrm{L})$ & $\mathrm{LYM}(\mathrm{K} / \mu \mathrm{L})$ & $\mathrm{MONO}(\mathrm{K} / \mu \mathrm{L})$ \\
\hline PYO & $5.56 \pm 0.21$ & $33.96 \pm 1.48$ & $12.05 \pm 0.53$ & $44.24 \pm 5.26$ & $20.46 \pm 2.48$ & $13.17 \pm 3.26$ & $11.74 \pm 2.38$ \\
$\mathrm{H}$ & $7.43 \pm 0.28$ & $51.01 \pm 2.63$ & $17.31 \pm 0.66$ & $10.88 \pm 0.68$ & $7.85 \pm 0.63$ & $2.61 \pm 0.33$ & $0.91 \pm 0.05$ \\
& $* *$ & $* *$ & $* *$ & $* *$ & $* *$ & $*$ & $* *$ \\
\hline
\end{tabular}

RBC: Red blood cell; HCT: Hematocrit; HGB: Hemoglobin; WBC: White blood cell; NEU: Neutrophils; LYM: Lymphocytes; MONO: Monocytes; ${ }^{*} P$ $<0.01 ; * * P<0.001$.

Table 3. Pearson correlation assessment of hematological parameters and hemodynamic indices.

\begin{tabular}{|c|c|c|c|c|c|c|c|c|c|c|c|c|c|}
\hline & & UD & UWT & DUA & PI & RI & $\mathrm{RBC}$ & HCT & HGB & WBC & NEU & LYM & MONO \\
\hline UD & $\begin{array}{c}\text { PCC } \\
P\end{array}$ & 1 & $\begin{array}{c}0.457 \\
*\end{array}$ & $\begin{array}{c}-0.155 \\
\mathrm{~ns}\end{array}$ & $\begin{array}{c}-0.596 \\
* *\end{array}$ & $\begin{array}{c}-0.540 \\
* *\end{array}$ & $\begin{array}{c}-0.566 \\
* *\end{array}$ & $\begin{array}{c}-0.630 \\
* * *\end{array}$ & $\begin{array}{c}-0.611 \\
* *\end{array}$ & $\begin{array}{c}0.536 \\
* *\end{array}$ & $\begin{array}{c}0.346 \\
\mathrm{~ns}\end{array}$ & $\begin{array}{c}0.374 \\
\text { ns }\end{array}$ & $\begin{array}{c}0.562 \\
* *\end{array}$ \\
\hline UWT & $\begin{array}{c}\text { PCC } \\
P\end{array}$ & $\begin{array}{c}0.457 \\
*\end{array}$ & 1 & $\begin{array}{c}0.443 \\
*\end{array}$ & $\begin{array}{c}-0.630 \\
* * *\end{array}$ & $\begin{array}{c}-0.549 \\
* *\end{array}$ & $\begin{array}{c}-0.736 \\
* * *\end{array}$ & $\begin{array}{c}-0.752 \\
* * *\end{array}$ & $\begin{array}{c}-0.775 \\
* * *\end{array}$ & $\begin{array}{c}0.465 \\
*\end{array}$ & $\begin{array}{c}0.484 \\
*\end{array}$ & $\begin{array}{c}0.339 \\
\text { ns }\end{array}$ & $\begin{array}{c}0.420 \\
*\end{array}$ \\
\hline DUA & $\begin{array}{c}\text { PCC } \\
P\end{array}$ & $\begin{array}{c}-0.155 \\
n s\end{array}$ & $\begin{array}{c}0.443 \\
*\end{array}$ & 1 & $\begin{array}{c}-0.170 \\
n s\end{array}$ & $\begin{array}{c}-0.147 \\
\mathrm{~ns}\end{array}$ & $\begin{array}{c}-0.201 \\
\mathrm{~ns}\end{array}$ & $\begin{array}{c}-0.140 \\
\mathrm{~ns}\end{array}$ & $\begin{array}{c}-0.188 \\
\text { ns }\end{array}$ & $\begin{array}{c}0.203 \\
\mathrm{~ns}\end{array}$ & $\begin{array}{c}0.294 \\
\mathrm{~ns}\end{array}$ & $\begin{array}{c}0.296 \\
\text { ns }\end{array}$ & $\begin{array}{c}0.241 \\
\mathrm{~ns}\end{array}$ \\
\hline PI & $\begin{array}{c}\text { PCC } \\
P\end{array}$ & $\begin{array}{c}-0.596 \\
* *\end{array}$ & $\begin{array}{c}-0.630 \\
* * *\end{array}$ & $\begin{array}{c}-0.170 \\
n s\end{array}$ & 1 & $\begin{array}{c}0.953 \\
* * *\end{array}$ & $\begin{array}{c}0.617 \\
* *\end{array}$ & $\begin{array}{c}0.724 \\
* * *\end{array}$ & $\begin{array}{c}0.689 \\
* * *\end{array}$ & $\begin{array}{c}-0.606 \\
* *\end{array}$ & $\begin{array}{c}-0.548 \\
* *\end{array}$ & $\begin{array}{c}-0.303 \\
n s\end{array}$ & $\begin{array}{c}-0.370 \\
\text { ns }\end{array}$ \\
\hline RI & $\begin{array}{c}\text { PCC } \\
P\end{array}$ & $\begin{array}{c}-0.540 \\
* *\end{array}$ & $\begin{array}{c}-0.549 \\
* *\end{array}$ & $\begin{array}{c}-0.147 \\
\mathrm{~ns}\end{array}$ & $\begin{array}{c}0.953 \\
* * *\end{array}$ & 1 & $\begin{array}{c}0.517 \\
* *\end{array}$ & $\begin{array}{c}0.635 \\
* * *\end{array}$ & $\begin{array}{c}0.585 \\
* *\end{array}$ & $\begin{array}{c}-0.482 \\
*\end{array}$ & $\begin{array}{c}-0.445 \\
*\end{array}$ & $\begin{array}{c}-0.219 \\
n s\end{array}$ & $\begin{array}{c}-0.226 \\
\mathrm{~ns}\end{array}$ \\
\hline $\mathrm{RBC}$ & $\begin{array}{c}\mathrm{PCC} \\
P\end{array}$ & $\begin{array}{c}-0.566 \\
* *\end{array}$ & $\begin{array}{c}-0.736 \\
* * *\end{array}$ & $\begin{array}{c}-0.201 \\
\mathrm{~ns}\end{array}$ & $\begin{array}{c}0.617 \\
* *\end{array}$ & $\begin{array}{c}0.517 \\
* *\end{array}$ & 1 & $\begin{array}{c}0.960 \\
* * *\end{array}$ & $\begin{array}{c}0.963 \\
* * *\end{array}$ & $\begin{array}{c}-0.594 \\
* *\end{array}$ & $\begin{array}{c}-0.529 \\
* *\end{array}$ & $\begin{array}{c}-0.335 \\
\text { ns }\end{array}$ & $\begin{array}{c}-0.442 \\
\quad *\end{array}$ \\
\hline HCT & $\begin{array}{c}\mathrm{PCC} \\
P\end{array}$ & $\begin{array}{c}-0.630 \\
* *\end{array}$ & $\begin{array}{c}-0.752 \\
* * *\end{array}$ & $\begin{array}{c}-0.140 \\
\mathrm{~ns}\end{array}$ & $\begin{array}{c}0.724 \\
* * *\end{array}$ & $\begin{array}{c}0.635 \\
* * *\end{array}$ & $\begin{array}{c}0.960 \\
* * *\end{array}$ & 1 & $\begin{array}{c}0.975 \\
* * *\end{array}$ & $\begin{array}{c}-0.628 \\
* * *\end{array}$ & $\begin{array}{c}-0.563 \\
* *\end{array}$ & $\begin{array}{c}-0.411 \\
*\end{array}$ & $\begin{array}{c}-0.518 \\
* *\end{array}$ \\
\hline HGB & $\begin{array}{c}\text { PCC } \\
P\end{array}$ & $\begin{array}{c}-0.611 \\
* *\end{array}$ & $\begin{array}{c}-0.775 \\
* * *\end{array}$ & $\begin{array}{c}-0.188 \\
n s\end{array}$ & $\begin{array}{c}0.689 \\
* * *\end{array}$ & $\begin{array}{c}0.585 \\
* *\end{array}$ & $\begin{array}{c}0.963 \\
* * *\end{array}$ & $\begin{array}{c}0.975 \\
* * *\end{array}$ & 1 & $\begin{array}{c}-0.697 \\
* * *\end{array}$ & $\begin{array}{c}-0.616 \\
* *\end{array}$ & $\begin{array}{c}-0.441 \\
*\end{array}$ & $\begin{array}{c}-0.519 \\
* *\end{array}$ \\
\hline WBC & $\begin{array}{c}\text { PCC } \\
P\end{array}$ & $\begin{array}{c}0.536 \\
* *\end{array}$ & $\begin{array}{c}0.465 \\
*\end{array}$ & $\begin{array}{c}0.203 \\
\mathrm{~ns}\end{array}$ & $\begin{array}{c}-0.606 \\
* *\end{array}$ & $\begin{array}{c}-0.482 \\
\quad *\end{array}$ & $\begin{array}{c}-0.594 \\
* *\end{array}$ & $\begin{array}{c}-0.628 \\
* * *\end{array}$ & $\begin{array}{c}-0.691 \\
* * *\end{array}$ & 1 & $\begin{array}{c}0.651 \\
* * *\end{array}$ & $\begin{array}{c}0.639 \\
* * *\end{array}$ & $\begin{array}{c}0.597 \\
* *\end{array}$ \\
\hline NEU & $\begin{array}{c}\text { PCC } \\
P\end{array}$ & $\begin{array}{c}0.346 \\
\mathrm{~ns}\end{array}$ & $\begin{array}{c}0.484 \\
*\end{array}$ & $\begin{array}{c}0.294 \\
\mathrm{~ns}\end{array}$ & $\begin{array}{c}-0.548 \\
* *\end{array}$ & $\begin{array}{c}-0.445 \\
*\end{array}$ & $\begin{array}{c}-0.529 \\
* *\end{array}$ & $\begin{array}{c}-0.563 \\
* *\end{array}$ & $\begin{array}{c}-0.616 \\
* *\end{array}$ & $\begin{array}{c}0.651 \\
* * *\end{array}$ & 1 & $\begin{array}{c}0.281 \\
\text { ns }\end{array}$ & $\begin{array}{c}0.381 \\
\mathrm{~ns}\end{array}$ \\
\hline LYM & $\begin{array}{c}\mathrm{PCC} \\
P\end{array}$ & $\begin{array}{c}0.374 \\
\mathrm{~ns}\end{array}$ & $\begin{array}{c}0.339 \\
\mathrm{~ns}\end{array}$ & $\begin{array}{c}0.296 \\
\mathrm{~ns}\end{array}$ & $\begin{array}{c}-0.303 \\
\mathrm{~ns}\end{array}$ & $\begin{array}{c}-0.219 \\
\mathrm{~ns}\end{array}$ & $\begin{array}{c}-0.335 \\
\text { ns }\end{array}$ & $\begin{array}{c}-0.411 \\
*\end{array}$ & $\begin{array}{c}-0.441 \\
*\end{array}$ & $\begin{array}{c}0.639 \\
* * *\end{array}$ & $\begin{array}{c}0.281 \\
\mathrm{~ns}\end{array}$ & 1 & $\begin{array}{c}0.734 \\
* * *\end{array}$ \\
\hline MONO & $\begin{array}{c}\mathrm{PCC} \\
P\end{array}$ & $\begin{array}{c}0.562 \\
* *\end{array}$ & $\begin{array}{c}0.420 \\
*\end{array}$ & $\begin{array}{c}0.241 \\
\mathrm{~ns}\end{array}$ & $\begin{array}{c}-0.370 \\
\mathrm{~ns}\end{array}$ & $\begin{array}{c}-0.226 \\
n s\end{array}$ & $\begin{array}{c}-0.442 \\
*\end{array}$ & $\begin{array}{c}-0.518 \\
* *\end{array}$ & $\begin{array}{c}-0.519 \\
* *\end{array}$ & $\begin{array}{c}0.597 \\
* *\end{array}$ & $\begin{array}{c}0.381 \\
\mathrm{~ns}\end{array}$ & $\begin{array}{c}0.734 \\
* * *\end{array}$ & 1 \\
\hline
\end{tabular}

PCC: Pearson correlation coefficients; P: Significance; UD: Uterine diameter; UWT: Uterine wall thickness; DUA: Diameter of uterine artery; PI: Pulsatility index; RI: Resistance index; RBC: Red blood cell; HCT: Hematocrit; HGB: Hemoglobin; WBC: White blood cell; NEU: Neutrophil; LYM: Lymphocyte; MONO: Monocyte; ${ }^{*} P<0.05$; $* * P<0.01$; *** $P<0.001$; ns: $P>0.05$. 
Z.G. Uçmak, I. Kurban \& M. Uçmak. 2021. Assessment of Hematological Parameters and Uterine Hemodynamic Indices

\section{DISCUSSION}

Ultrasonography is a useful and most reliable tool to diagnose pyometra [4]. Cystic endometrial hyperplasia $(\mathrm{CEH})$ is a predisposing factor for development of the pyometra in bitches [16]. Besides, naturally occurring $\mathrm{CEH}$ and pyometra can arise independently from each other [8]. In USG examination, thick uterine walls with multiple cystic structures, absence of intraluminal fluid and $2 \mathrm{~cm}$ in diameter of uterine horn were defined as CEH in a bitch by Hagman [16]. In contrast with the previous report [16], absence of cystic structures and presence of pus accumulation were viewed in USG examination of the bitches whose uterine diameter were less than $2 \mathrm{~cm}$. It was explained by the reported research that $\mathrm{CEH}$ and pyometra can be formed independently of each other [8]. Increase in both UWT and UD in the presence of pyometra was determined in this study, similar with the researchers [36]. Thickened uterine walls can be explained by an active proliferative mechanism of endometrium. Additionally, the enlarged uterine body and horn diameter exhibit the development of intense exudative processes due to the higher proliferative stimulation in uterine infections [4]. Jitpean et al. [18] reported that closed cervix pyometra was more severe illness than open cervix pyometra. Contradictorily with the researchers [18], all evaluated parameters were not significantly different in regard to cervical patency in this study. These results may be due to the early presentation of the bitches to the clinic. Thus, the exposure time to the effects of the disease was relatively short.

Doppler USG was utilized to evaluate the uterine blood flow, and DUA was measured on color mapped images similar to Alvarez-Clau \& Liste [1]. It was reported that UA appeared less than $2 \mathrm{~mm}$ in nonestrous bitch [1] and in bitches with CEH [11]. Similar with the researchers [1] DUA in both groups were less than $2 \mathrm{~mm}$ in this study. England et al. [11] observed approximately $2 \mathrm{~mm}$ of DUA in healthy bitches and in bitches with CEH before and after mating. In the present study, DUA in group PYO was higher than group $\mathrm{H}$. To our knowledge, this was the first report to detect the significant differences in DUA between the healthy diestrous bitches and bitches with pyometra. Dickey [9] notified that UA diameter range was 0.2-0.5 $\mathrm{cm}$ in non-pregnant women and it became ascendant in pregnant women. The differences between studies can be explained by the elevated levels of DUA in group PYO occurring in accordance with the enlargement of the uterus due to the pus accumulation into the uterine lumen.

Pyometra is a common gyneacological disease of intact females that occurs as a result of uterine inflammation [31]. Prostoglandin metabolites (PGFM, PGF2 $\alpha$, PGE) play an important role in the inflammatory process $[14,30]$. Elevated levels of intra-uterine concentration of prostaglandins may lead to increase in the uterine perfusion [20]. Thereby, inflammatory processes lead to a diminution in hemodynamic indices of UAs in several mammalian spices [32]. Similarly to the previous reports [20,32], reduction of hemodynamic indices supposed to be as a result of inflammatory process in bitches with pyometra in present study.

This study shows the significant differences among the hemodynamic indices of the group $\mathrm{H}$ and group PYO. The researchers [23] who investigated uterine hemodynamics along the oestrous cycle, indicated that oestrogenic phase affects the uterine blood flow in bitches and they reported range of the PI in diestrous bitches as 3.1-3.9. Veiga et al. [36] observed that the mean PI value in bitches with pyometra was lower than the bitches with mucometra and diestrous healthy females. It has been reported that the decrease in PI reflects the rise in UA perfusion [23]. In the present study, decrease in the mean PI value of the bitches in group PYO was supported due to the increase in UA perfusion in consistent with the previous reports $[23,36]$.

Uterine infections were associated with increase in uterine blood flow. Elevated uterine blood flow, vasodilatation and angiogenesis arise during inflammatory response [25]. Opposite results were obtained by England et al. [11] who indicated that mean $\mathrm{RI}$ in healthy diestous bitches $(0.56 \pm 0.02)$ was lower than in bitches with endometrial hyperplasia $(0.67 \pm$ 0.02). Similar with the researchers $[3,36]$, the reduced vascular resistance was detected in group PYO than Group H. Resembling results with the previous reports $[3,36]$ can be explained by the association between uterine infections and uterine blood flow as Özbay \& Deveci [25] reported.

Similar with the previous reports [2,29], WBC, NEU, LYM, MONO counts in bitches with pyometra were increased in the present study. Elevated levels of leukocytes in bitches with pyometra were associated with worsening prognosis [26]. The results showed 
that leukocyte changes were induced by stimulation of bone marrow in the inflammatory process and acute phase reaction [34]. Similar with the researchers [29]; reduced levels of RBC, HGB and $\mathrm{HCT}$ in group PYO were observed in this study. The occurrence of anemia could be explained by the decreased erythropoiesis in the bone marrow as a result of chronic uterine inflammatory disease [35]. Erythrocyte diapedesis into the lumen of the uterus, toxic depression of erythropoiesis in the bone marrow could cause anemia (normocytic and normochromic) [26,34].

Bree et al. [7] investigated the correlation between radiological and hematological findings of canine pyometra and they reported that leukocyte numbers were increased when the uterine body was enlarged. In line with Bree et al. [7], uterine distention was strongly associated with the elevated levels of WBC and MONO in the present study. The researchers noticed that an increase in vascular resistance of UA may act a role in thinning of the endometrium in women [28]. It was postulated that growth on the glandular epithelium of the uterus may be prevented by the increase in vascular resistance [33]. In agreement with the reports $[28,33]$ on human literature, UWT was negatively correlated with RI in this study. The researchers [22] reported that velocity of the blood flow decreases, when the blood viscosity increases dramatically. In this study, RBC, HGB and HCT values were strongly correlated with PI and RI. In agreement with the previous report [22], similar results exhibit the relation between blood viscosity parameters and hemodynamic indices of UA. The blood viscosity was directly associated with a relative percentage of RBCs called HCT in blood circulation. Because the resistance to blood flow usually occurs in small vessels and capillaries, the viscosity was important to determine the amount of the blood into the circulatory system [22].

\section{CONCLUSION}

In conclusion, hematological and hemodynamic changes were observed in bitches with pyometra. Besides, hematological parameters were strongly correlated with hemodynamic indices. Reduced RBC, HGB and HCT levels, decreased PI and RI values and elevated levels of UD, UWT, DUA were observed in group PYO. To our knowledge, this was the first study that observed the increase in DUA during pyometra in bitches.

\author{
MANUFACTURERS \\ ${ }^{1}$ ADR Group, Mediko Kimya. Istanbul, Turkey. \\ ${ }^{2}$ Olympus Corporation. Tokyo, Japan. \\ ${ }^{3}$ Esaote SPA. Genova, GE, Italy. \\ ${ }^{4}$ Becton, Dickinson and Company. Franklin Lakes, NJ, USA. \\ ${ }^{5}$ IDEXX Laboratories Inc. Westbrook, ME, USA. \\ ${ }^{6}$ SPSS Inc. Chicago, IL, USA.
}

Ethical approval. The study was approved by the Istanbul University-Cerrahpasa Unit Ethics Committee (protocol no. 2020/14).

Declaration of interest. The authors report no conflicts of interest. The authors alone are responsible for the content and writing of paper.

\section{REFERENCES}

1 Alvares-Clau A \& Liste F. 2005. Ultrasonographic characterization of the uterine artery in the nonestrus bitch. Ultrasound in Medicine and Biology. 31(12): 1583-1587.

2 Bartoskova A., Vitasek R., Leva L. \& Faldyna M. 2007. Hysterectomy leads to fast improvement of haematological and immunological parameters in bitches with pyometra. Journal of Small Animal Practice. 48(10): 564-568.

3 Batista P.R., Gobello C., Rube A., Corrada Y.A., Tortora M. \& Blanco P.G. 2016. Uterine blood flow evaluation in bitches suffering from cystic endometrial hyperplasia (CEH) and CEH-pyometra complex. Theriogenology. 85(7): 1258-1261.

4 Bigliardi E., Parmigiani E., Cavirani S., Luppi A., Bonati L. \& Corradi A. 2004. Ultrasonography and cystic hyperplasia-pyometra complex in the bitch. Reproduction in Domestic Animal. 39(3): 136-140.

5 Blanco P.G., Rube A., Merlo M.L., Batista P.R., Arioni S., Knudsen I.L., Tortora M. \& Gobello C. 2018. Uterine twodimensional and Doppler ultrasonographic evaluation of feline pyometra. Reproduction in Domestic Animal. 53(3): 70-73.

6 Bollwein H., Heppelmann M. \& Lüttgenau J. 2016. Ultrasonographic Doppler use for female reproduction management. Veterinary Clinics of North America: Food Animal Practice. 32(1): 149-164.

7 Bree H.V., Schepper J.D. \& Capiau E. 1988. The significance of radiology in the diagnosis of pyometra (endometritis post oestrum) in dogs: An evaluation of the correlation between radiographic and laboratory finding in 131 cases. Zentralblatt fur Veterinarmedizin. Reihe A. 35(3): 200-206. 
8 De Bosschere H., Ducatelle R., Vermeirsch H., Van Den Broeck W. \& Coryn M. 2001. Cystic endometrial hyperplasia-pyometra complex in the bitch: should the two entities be disconnected. Theriogenology. 55(7): 1509-1519.

9 Dickey R.P. 1997. Doppler ultrasound investigation of uterine and ovarian blood flow in infertility and early pregnancy. Human Reproduction Update. 3(5): 467-503.

10 El-Mazny A., Abou-Salem N. \& ElShenoufy H. 2013. Doppler study of uterine hemodynamics in women with unexplained infertility. European Journal of Obstetrics \& Gynecology and Reproductive Biology. 171(1): 84-87.

11 England G.C.W., Moxon R. \& Freeman S.L. 2012. Delayed uterine fluid clearance and reduced uterine perfusion in bitches with endometrial hyperplasia and clinical management with postmating antibiotic. Theriogenology. 78(7): 1611-1617.

12 Freitas L.A., Mota G.L., Silva H.V.R. \& Silva L.D.M. 2017. Two-dimensional sonographic and Doppler changes in the uteri of bitches according to breed, estrus cycle phase, parity, and fertility. Theriogenology. 95: 171-177.

13 Gürbulak K., Pancarcı Ş.M., Ekici H., Konuk C., Kırşan İ., Uçmak M. \& Toydemir S. 2005. Use of aglepristone and aglepristone + intrauterine antibiotic for the treatment of pyometra in bitches. Acta Veterinaria Hungarica. 53(2): 249-255.

14 Hagman R., Kindahl H. \& Lagerstedt A.S. 2006. Pyometra in bitches induces elevated plasma endotoxin and prostaglandin F2a metabolite level. Acta Veterinaria Scandinavica. 47(1): 55-68.

15 Hagman R. 2012. Clinical and molecular characteristics of pyometra in female dogs. Reproduction in Domestic Animals. 47(6): 323-325.

16 Hagman R. 2018. Pyometra in small animals. Veterinary Clinics of North America: Small Animal Practice. 48(4): 639-661.

17 Jisna K.S. \& Sivaprasad M.S. 2020. Canine pyometra: An overview. Raksha Technical Review. 10(1): 53-56.

18 Jitpean S., Ambrosen A., Emanuelson U. \& Hagman R. 2017. Closed cervix is associated with more severe illness in dogs with pyometra. BMC Veterinary Research. 13: 11.

19 Kaymaz M., Baştan A., Erünal N., Aslan S. \& Fındık M. 1999. The use of laboratory findings in the diagnosis of CEH-Pyometra complex in the bitch. Turkish Journal of Veterinary and Animal Sciences. 23(2): 127-133.

20 Koresawa M. 1981. Effects of prostaglandin E1 analogue and prostaglandin F2 alpha on uterine contraction, uterine blood flow and fetal circulation in pregnant and nonpregnant rabbits. Nihon Sanka Fujinka Gakkai Zasshi. 33(1): 60-66.

21 Nelson R.W. \& Feldman E.C. 1986. Pyometra. Veterinary Clinics of North America: Small Animal Practice. 16(3): 561-576.

22 Nelson T.R. \& Pretorius D.H. 1988. The Doppler signal: where does it come from and what does it mean? American Journal of Roentgenology. 151(3): 439-447.

23 Nogueira I.B., Almeida L.L., Angrimani D.S.R., Brito M.M., Abreu A.A. \& Vannucchi C.I. 2017. Uterine haemodynamic, vascularization and blood pressure changes along the oestrous cycle in bitches. Reproduction in Domestic Animal. 52(2): 52-57.

24 Oliveira K.S. 2007. Cystic endometrial hyperplasia complex. Acta Scientiae Veterinariae. 35(2): 270-272.

25 Özbay K. \& Deveci S. 2011. Relationships between transvaginal colour Doppler findings, infectious parameters and visual analogue scale scores in patients with mild acute pelvic inflammatory disease. European Journal of Obstetrics \& Gynecology and Reproductive Biology. 156(1): 105-108.

26 Prasad V.D., Kumar P.R. \& Sreenu M. 2017. Pyometra in bitches: A review of literature. Research \& Reviews: Journal of Veterinary Science and Technology. 6(2): 12-20.

27 Quartuccio M., Liotta L., Cristarella S., Lanteri G., Ieni A., D’Arrigo T. \& De Majo M. 2020. Contrast-enhanced ultrasound in cystic endometrial hyperplasia-pyometra complex in the bitch: A preliminary study. Animals. 10(8): 1368.

28 Richter K.S., Bugge K.R., Bromer J.G. \& Levy M.J. 2007. Relationship between endometrial thickness and embryo implantation, based on 1,294 cycles of in vitro fertilization with transfer of two blastocyst-stage embryos. Fertility and Sterility. 87(1): 53-59.

29 Shah S.A., Sood N.K., Wani B.M., Rather M.A., Beigh A.B. \& Amin U. 2017. Haemato-biochemical studies in canine pyometra. Journal of Pharmacognosy and Phytochemistry. 6(4): 14-17.

30 Singh L.K., Patra M.K., Mishra G.K., Saxena A.C., De U.K., Singh S.K., Kumar H. \& Krishnaswamy N. 2020. Effect of systemic inflammatory response syndrome (SIRS) on prostaglandin metabolite and oxidative stress in canine pyometra. Indian Journal of Animal Sciences. 90(4): 569-573. 
Z.G. Uçmak, İ. Kurban \& M. Uçmak. 2021. Assessment of Hematological Parameters and Uterine Hemodynamic Indices in Bitches with Pyometra. Acta Scientiae Veterinariae. 49: 1796.

31 Smith F.O. 2006. Canine pyometra. Theriogenology. 66: 610-612.

32 Still J.G. \& Greiss Jr. F.C. 1978. The effect of prostaglandins and other vasoactive substances on uterine blood flow and myometrial activity. The American Journal of Obstetrics and Gynecology. 130(1): 1-8.

33 Takasaki A., Tamura H., Miwa I., Taketani T., Shimamura K. \& Sugino N. 2010. Endometrial growth and uterine blood flow: a pilot study for improving endometrial thickness in the patients with a thin endometrium. Fertility and Sterility. 93(6): 1851-1858.

34 Tanja P., Barbara C., Kristina D., Pecar J., Alenka N. \& Butinar J. 2006. Haemostasis impairment in bitches with pyometra. Acta Veterinaria- Beograd. 56(5-6): 529-540.

35 Thangamani A., Srinivas M. \& Chandra Prasad B. 2018. Pyometra in bitches: A critical analysis. International Journal of Science, Environment and Technology. 7(3): 1072-1078.

36 Veiga G.A.L., Miziara R.H., Angrimani D.S.R., Papa P.C., Cogliati B. \& Vannucchi C.I. 2017. Cystic endometrial hyperplasia-pyometra syndrome in bitches: identification of hemodynamic, inflammatory, and cell proliferation changes. Biology of Reproduction. 96(1): 58-69. 